\title{
Analysis on the Effect of 360 Degree Performance Appraisal on Middle Level Managers in IT Industry
}

\author{
Magdalene Peter, S. Fabiyola Kavitha
}

\begin{abstract}
Most organizations are contending in the differing worldwide markets, and upper hand through human capital is winding up significant. Worker improvement for high profitability and the utilization of successful devices to gauge their presentation are thusly central. One such device is the 360-degree execution evaluation framework. The investigation on the adequacy of the 360-degree execution examination was led on a chose steel association. The essential goal of the examination study was to decide if the current 360-degree execution assessment framework the association uses is viable or whether there is a need to investigate other worker assessment and criticism frameworks over the business to recognize the best practice. Builds that were estimated are the effect of 360-degree examination on the worker inspiration and execution, work fulfillment, the organisation "s execution, progression arranging just as preparing and improvement. The discoveries demonstrated that the 360-degree evaluation framework is successful in the vast majority of these regions. The discoveries will likewise help the executives with a superior comprehension of where the procedure has fizzled and what holes should be filled.
\end{abstract}

Keywords: Performance management system, 360 degree, feedback, performance appraisal

\section{INTRODUCTION}

Execution examination is a strategy by which the exhibition of a worker is estimated (by and large as far as quality, amount, cost and Time). The underlying foundations of Performance Appraisal can be found in Frederick Winslow Taylor's time and movement study. Execution evaluation is a piece of profession improvement[1],[3],[5].

\section{A. Need For the Study}

- Self-improvement and individual directing.

- Organized preparing and improvement.

- Team building.

- Performance the board.

- Strategic or association advancement.

- Validation of preparing and different activities.

\section{B. Scope of the Study}

Revised Manuscript Received on July 22, 2019

Magdalene Peter , Department of MBA, Bharath Institute of Higher Education and Research, Chennai, India. Email: magdalene.bsb@gmail.com

Dr. S. Fabiyola Kavitha, Department of MBA, Bharath Institute of Higher

Education and Research, Chennai, India Email: fabiyolakavitha@gmail.com
The accompanying four powers have energized the quick development of 360-degree criticism in the ongoing years[2],[4],[6]:

- Changes in the jobs of the worker and what the association expects of the representative, for example, support given to cooperation and group working, ceaseless upgrades, decrease in representative numbers and levels of the executives, adaptability and so forth.

- An accentuation on estimation inside associations to survey sees, recommendations, demeanors, inspirations, confidence, characters, bent, abilities, potential and profession desire of representatives.

- The impact of new administration ideas.

- Management demeanors and responsiveness.

\section{C. limitations of the Study}

Despite the fact that the exploration was done in an efficient and arranged way, there were a couple of obstacles that couldn't be survived. These comprised the restrictions of the exploration. Care was taken that the underneath constraints did not influence the examination results to such an extent.

- Time imperative was the greatest confinement. The venture must be finished inside 3 months and consequently the example size must be lesser.

\section{- Area choice must be done on an irregular premise.}

- In a few cases administrators were not prepared ti give the data.

- One issue that each questioner appearances is the readiness of the clients in topping off the survey[7],[9],[11].

- The respondents have some classified issues over the organization. In this way, it is hard to discover the sentiment precisely.

The impact of the contenders can't be estimated by methods for this examination.

\section{Objectives of the Study \\ - To evaluate the overall performance of employees.}


- To evaluate the performance of the organisation.

The components of the study includes:

- Determining employee' s contribution \& commitment towards performance appraisal system.

- Determining the steps taken by the organization to carry out the performance appraisal.

- Determining the effectiveness of steps taken to carry out the performance appraisal.

\section{RESEARCH DESIGN}

The research method used for the research purpose is descriptive in nature. The population for this study is large scale IT companies in Chennai. Therefore the study has done on census survey[8],[10],[12].

A list of large IT companies (only public limited) functioning in Chennai(223) was prepared and these companies were stratified into Application programming, Client server,

E-Commerce,

Embedded/EDA/VLSI/ASIC/Chip Design, Software programming, Mainframe, ERP/CRM, DBA/Warehousing, QA/Testing, Network Admin/Security and Tech support/Telecom/Hardware.

Based on judgment and owing to time constraint the researcher identified 130 employees for personal interviews. The levels of these employees are General Manager, Assistant Manager and Manager.

In this study primary data is directly collected from managers with the help of scheduled questionnaires and interview method respectively[13], [15],[17].

The researcher has also collected data from secondary sources. Some of the secondary sources are:
$\square$ Websites
Magazines
Books

Table - 1 Table Showing How Do The Employees Find The Job

\begin{tabular}{|l|l|l|l|}
\hline S.NO & CHOICE & $\begin{array}{l}\text { NO OF } \\
\text { RESPONDENTS }\end{array}$ & PERCENTAGE (\%) \\
\hline 1. & EXCELLENT & 34 & 26.15 \\
\hline 2. & GOOD & 62 & 47.69 \\
\hline 3. & SATISFIED & 27 & 20.77 \\
\hline 4. & BAD & 7 & 5.38 \\
\hline \multicolumn{2}{|l|}{ TOTAL } & $\mathbf{1 3 0}$ & $\mathbf{1 0 0}$ \\
\hline
\end{tabular}

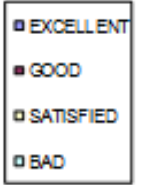

Figure - 1 Figure Showing How Do The Employees Find The Job

Inference:

$47.69 \%$ of the employees find the job to be good, $26.15 \%$ of the employees finds the job to be excellent, $20.77 \%$ of the employees are satisfied with the job whereas in few cases the employees finds the job to be bad.

Table - 2 Table Showing If You Have To Do A Work Which Is Entirely Different From The Present One, Can The Employee Excel

\begin{tabular}{|l|l|l|l|}
\hline S.NO & CHOICE & NO OF RESPONDENTS & PERCENTAGE (\%) \\
\hline 1. & NEVER & 9 & 6.92 \\
\hline 2. & SOMETIMES & 38 & 29.23 \\
\hline 3. & OFTEN & 24 & 18.46 \\
\hline 4. & ALWAYS & 59 & 45.39 \\
\hline \multicolumn{2}{|l|}{ TOTAL } & $\mathbf{1 3 0}$ & $\mathbf{1 0 0}$ \\
\hline
\end{tabular}

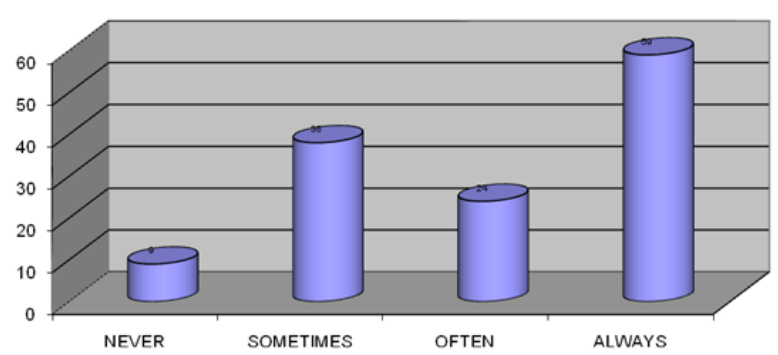

Figure - 2 Figure Showing If You Have To Do A Work Which Is Entirely Different From The Present One, Can The Employee Excel

\section{Inference:}

If the employee is asked to work alone $45.39 \%$ of the employees will always excel, $29.23 \%$ of the employees will sometimes excel, $18.46 \%$ will often excel whereas in few cases the employee never excel.

Table - 3 Table Showing Whether The Employee Need Training 


\begin{tabular}{|l|l|l|l|}
\hline S.NO & OPTIONS & $\begin{array}{l}\text { NO } \\
\text { RESPONDENTS }\end{array}$ & PERCENTAGE (\%) \\
\hline 1. & YES & 90 & 69.2 \\
\hline 2. & NO & 40 & 30.8 \\
\hline \multicolumn{2}{|l|}{ TOTAL } & $\mathbf{1 3 0}$ & $\mathbf{1 0 0}$ \\
\hline
\end{tabular}

\section{Inference:}

$69.2 \%$ of the employee need training whereas $30.8 \%$ of the employee does not training.

Table - 4 Table Showing Whether The Superiors Allocate The Work Which Are Highly Confidential

\begin{tabular}{|l|l|l|l|}
\hline S.NO & CHOICE & NO OF RESPONDENTS & PERCENTAGE (\%) \\
\hline 1. & NEVER & 42 & 32.31 \\
\hline 2. & SOMETIMES & 28 & 21.54 \\
\hline 3. & OFTEN & 24 & 18.46 \\
\hline 4. & ALWAYS & 36 & 27.69 \\
\hline \multicolumn{2}{|l}{ TOTAL } & $\mathbf{1 3 0}$ & $\mathbf{1 0 0}$ \\
\hline
\end{tabular}

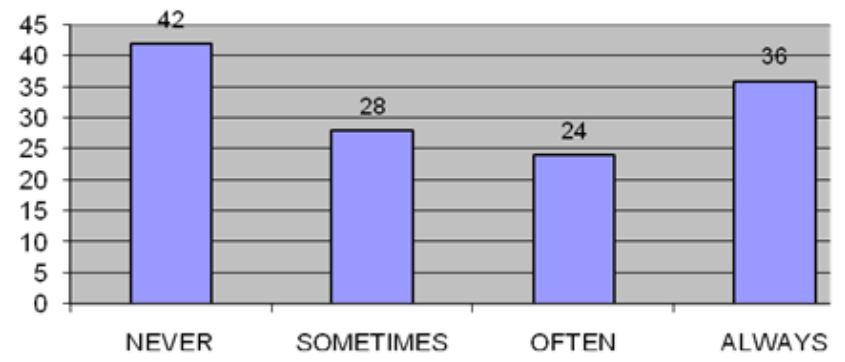

Figure - 3 Figure Showing Whether The Superiors Allocate The Work Which Are Highly Confidential

\section{Inference:}

$32.31 \%$ of the superiors never allocate the work, which are highly confidential, $27.69 \%$ always allocate the work which are highly confidential, $21.54 \%$ will sometimes allocate whereas in few cases the superiors often allocate the work which are highly confidential

Table - 5 Table Showing Whether The Employees Get On With Others In The Company

\begin{tabular}{|l|l|l|l|}
\hline S.NO & CHOICE & NO OF RESPONDENTS & PERCENTAGE (\%) \\
\hline 1. & UNSATISFACTORY & 26 & 20 \\
\hline 2. & AVERAGE & 67 & 51.54 \\
\hline 3. & OUTSTANDING & 37 & 28.46 \\
\hline \multicolumn{2}{|l|}{ TOTAL } & $\mathbf{1 3 0}$ & $\mathbf{1 0 0}$ \\
\hline
\end{tabular}

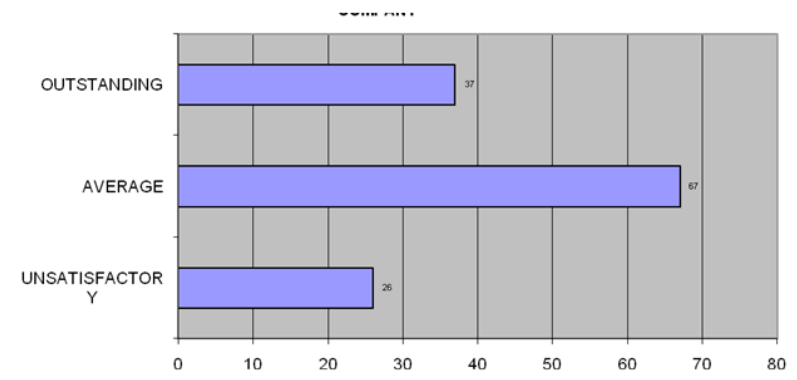

Figure - 4 Figure Showing Whether The Employees Get On With Others In The Company

\section{Inference:}

51.54\% Of The Employees Get On With Others In The Company, Outstanding Relationship Is Only $28.46 \%$ And Unsatisfactory Is $20 \%$.

Table-6 Table Showing Whether The Abilities Can Be Better Utilised

\begin{tabular}{|l|l|l|l|}
\hline S.NO & CHOICE & NO OF RESPONDENTS & PERCENTAGE (\%) \\
\hline 1. & NEVER & 42 & 32.31 \\
\hline 2. & SOMETIMES & 28 & 21.54 \\
\hline 3. & OFTEN & 24 & 18.46 \\
\hline 4. & ALWAYS & 36 & 27.69 \\
\hline \multicolumn{2}{|l|}{ TOTAL } & $\mathbf{1 3 0}$ & $\mathbf{1 0 0}$ \\
\hline
\end{tabular}

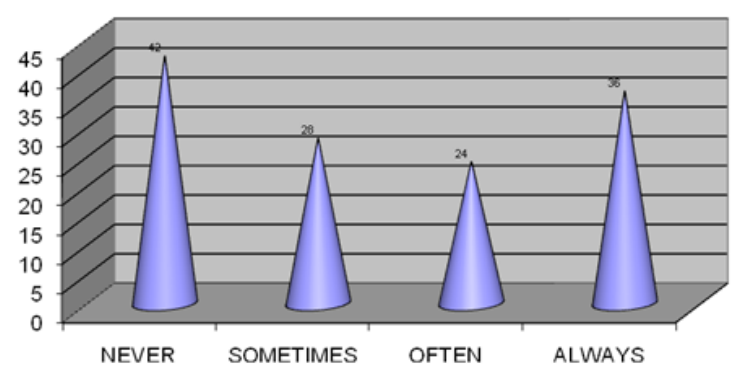

Fifur - 5 Figure Showing Whether The Abilities Can Be Better Utilised

\section{Inference:}

$32.31 \%$ of the abilities can never be better utilized, $27.69 \%$ can always be better utilized, $21.54 \%$ can be sometimes utilized whereas in few cases it is often.

\section{RESULTS AND DISCUSSIONS}

- If the employee is asked to work alone $44.6 \%$ of the employees sometimes excel, $36.9 \%$ of the employees will always excel, $10.8 \%$ will often excel whereas in few cases the employee never excel[14],[16], [18].

- If the employee is made part of a team, $45.39 \%$ of the employees will always get things done, $29.23 \%$ may get the things done $18.46 \%$ will often get the things done whereas in few cases the employee never get things done. 


\section{Analysis on the Effect of 360 Degree Performance Appraisal on Middle Level Managers in IT Industry}

- $47.69 \%$ of the employees find the job to be good, $26.15 \%$ finds the job to be excellent, $20.77 \%$ are satisfied with the job whereas in few cases the employees finds the job to be bad.

- If the employee asked to work alone $45.39 \%$ of the employees will always excel, $29.23 \%$ will sometimes excel, $18.46 \%$ will often excel whereas in few cases the employee never excel.

$69.2 \%$ of the employee need training whereas $30.8 \%$ of the employee does not training[19],[21],[23].

- $\quad 32.31 \%$ of the superiors never allocate the work which are highly confidential, $27.69 \%$ always allocate the work, $21.54 \%$ will sometimes allocate whereas in few cases the superiors often allocate the work which are highly confidential.

- $51.54 \%$ of the employees get on with others in the company, outstanding relationship is only $28.46 \%$ and unsatisfactory is $20 \%$.

$32.31 \%$ of the abilities can never be better utilized, $27.69 \%$ can always be better utilised,21.54\% can be sometimes utilized whereas in few cases it is often.

$36.92 \%$ of the employees will sometimes accept responsibility for decisions, $23.08 \%$ will often \& always accept the responsibility whereas in few cases it is never.

- The ratings of the employee assessment questionnaire for the particular factors are mostly sometimes, in some cases it is always whereas in few cases it is never in case of all the factors of employee assessment questionnaire[20],[22],[24].

- $\quad 36.92 \%$ of the employees will sometimes analyze and identify the problems, $31.54 \%$ will always analyze and identify the problems, $22.31 \%$ will often do the job, whereas in few cases it is never.

- $44.6 \%$ of the employees will sometimes identify the possible causes of problems and takes corrective action, $36.9 \%$ will always identify, $10.8 \%$ will often do the job whereas in few cases it is never.

- $44.62 \%$ of the employees sometimes plan responsibly for departmental budgeted areas, $29.23 \%$ will always plan, $16.92 \%$ will often plan whereas in few cases it is never.

- $30.77 \%$ of the employees always make difficult commitments, $29.23 \%$ sometimes make difficult commitments, $28.46 \%$ often make it whereas in few cases it is never.

- $\quad 36.92 \%$ of the employees sometimes report on internal customer satisfaction, $23.08 \%$ will often and always report whereas in few cases it is never.

- $52.31 \%$ of the employees sometimes identify the customer needs, $30.77 \%$ will often identifies,9.23\% will never do the job whereas in few cases it is never[25],[27],[29].

- $\quad 38.46 \%$ of the employees never listen to problems with genuine interest,36.92\% sometimes listens with genuine interest, $30.77 \%$ will always listen whereas in few cases it is never.
$34.62 \%$ of the employees often encourages the free expression of opinions without being defensive, $33.85 \%$ always encourages, $28.46 \%$ sometimes encourages whereas in few cases it is never.

$36.92 \%$ of the employee' $\mathrm{s}$ decisions often balance company' s profitability and customer needs,34.62\% always balance, $19.23 \%$ sometimes balance whereas in few cases it is never.

- $40.77 \%$ of the employees always select good people, $37.69 \%$ often select good people, $16.15 \%$ sometimes excel whereas in few cases it is never.

- $35.38 \%$ of the employees will often train and develop employees, $32.31 \%$ will always train, $24.62 \%$ will sometimes train whereas in few cases it is never.

- $49.23 \%$ of the employees always conduct staff meetings, $38.46 \%$ never conduct meetings, $26.15 \%$ sometimes do whereas in few cases it is never.

- $46.92 \%$ of the employees often sets challenging goals for self and others, $30.10 \%$ always set the goals, $16.15 \%$ sometimes set challenging goals whereas in few cases it is never.

- $39.23 \%$ of the employees often allocate decision making responsibilities to the staff,31.54\% always allocate, $18.46 \%$ sometimes allocate whereas in few cases it is never.

$39.23 \%$ of the employees always provide encouragement necessary to get the work done, $30.77 \%$ often does the job, $21.54 \%$ sometimes whereas in few cases it is never.

The ratings of the employee assessment questionnaire for the particular factors are mostly sometimes, in some cases it is always whereas in few cases it is never in case of all the factors of employee assessment questionnaire

\section{CONCLUSION}

The top administration should take up occasional projects to clarify the targets and the related issues to the administrators and questions ought to be altogether cleared.

It is important to improve the presentation investigation and audit framework in following territories[26],[28],[30]:

There ought to be clear meaning of remunerations dependent on execution

PA'S ought to have direct bearing on advancements

$\square$ Self-examination dialog with the surveying official and then the official account his evaluation will be perfect.

$\square$ Every year an evaluation letter ought to be given to workers since that can make a representative to indicate incredible fondness to their activity learned

$\square$ Subordinate and friends likewise ought to have a job in person's appraisal

Before or during PA, the revealing official may examine with the representative about his give or take indicates all together instruct and improved the worker's exhibition in future[31],[33]. 
Most of the appraisal depends on close to home collaboration with assessing official

$\square$ Instead of giving generally speaking rating in the paper, great specialists ought to be valued by the method for given additional advantages or augmentation

$\square$ Existing framework is great

$\square$ The choice got at execution examination ought to be actualized

\section{REFERENCES}

1) BharthVajan R., Ramachandran S.,Psychographic dimensions of training,2016,International Journal of Pharmacy and Technology,V-8,I-4,P-23727-23729

2) Balakrishnan P., Bharthvajan R.,A study on human resource planning in hospitals in Chennai City,2014,International Journal of Applied Engineering Research,V-9,I-22,P-7503-7507

3) Priyadarsini P., Bharthvajan R.,Role of emotional intelligence training programme in reducing the stress of the nurses,2014,International Journal of Applied Engineering Research,V-9,I-22,P-7411-7421

4) Kerinab Beenu G., Bharthvajan R.,Empirical analysis on the cosmetic buying behavior of young women in South India,2014,International Journal of Applied Engineering Research,V-9,I-22,P-7361-7366

5) Balakrishnan P., Bharthvajan R.,Whistling in the wind,2014,International Journal of Applied Engineering Research,V-9,I-22,P-7586-7593

6) Krishnan B., Peter M.,Health hazards of Indian Bpo employee-an alarming issue, 2014,International Journal of Applied Engineering Research,V-9,I-22,P-7336-7341

7) Kerinab Beenu G.H., Peter M.,Role of insurance in economic development,2014,International Journal of Applied Engineering Research,V-9,I-22,P-7532-7539

8) Balakrishnan P., Peter M., Priyadarsini P.,Efficiency of safety measures for wellbeing of employees in manufacturing industry,2014,International Journal of Applied Engineering Research,V-9,I-22,P-7376-7382

9) Anbarasi M., Praveen Kumar S.,Online sales promotions of herbal products and its effectiveness towards tanisha.com,2019,Indian Journal of Public Health Research and Development,V-10,I-1,P-195-200

10) Anbarasi M., Praveen Kumar S.,Various online marketing and promotions strategies to improve the validation towards the organic products in the pharmaceutical sectors, 2019,Indian Journal of Public Health Research and Development, V-10,I-1,P-263-269

11) Loganathan R., Praveen Kumar S.,Grievance handling a key factor for solving issues of employees in an organization,2014,International Journal of Applied Engineering Research,V-9,I-22,P-7483-7491

12) Loganathan R., Praveen Kumar S.,Study on preference of private label brands in super and Hypermarkets,2014,International Journal of Applied Engineering Research,V-9,I-22,P-7327-7335

13) Smitha M., Praveen Kumar S.,Understanding stress and its managementamong the nurses in Chennai city,2014,International Journal of Applied Engineering Research,V-9,I-22,P-7560-7565

14) Kerinab Beenu G.H., Praveen Kumar S.,A study on the investment behavior of Chennai investors in mutual fund schemes,2014,International Journal of Applied Engineering Research,V-9,I-22,P-7520-7525

15) Loganathan R., Praveen Kumar S.,Retention strategies key for organizational productivity,2014,International Journal of Applied Engineering Research,V-9,I-22,P-7443-7447

16) Pavithra J., Ganesan M., Brindha G.,State wise analysis of microfinance sector in India,2016,International Journal of Pharmacy and Technology,V-8,I-4,P-23417-23432

17) Pavithra J., Ganesan M.,A comparative study on microfinance in India and abroad,2016,International Journal of Applied Business and Economic Research,V-14,I-8,P-5471-5476

18) Pavithra J., Ganesan M.,A study on awareness and impact of micro-financial schemes,2016,International Journal of Applied Business and Economic Research,V-14,I-8,P-5449-5460

19) Senthilmurugan P., Pavithra J.,Consumer preference towards organised retailing with reference to Big Bazaar,2014,International Journal of Applied Engineering Research,V-9,I-22,P-7469-7475

20) Senthilmurugan P., Pavithra J.,Implication of social media marketing in growing healthcare industry,2014,International Journal of Applied Engineering Research,V-9,I-22,P-7448-7456

21) Loganathan R., Pavithra J.,Consumer perception towards private label brand over other brands in super markets and hypermarkets,2014,International Journal of Applied Engineering Research,V-9,I-22,P-7355-7360

22) Kerinab Beenu G., Pavithra J.,Tradeâ€"off between liquidity and profitability in logistics industry,2014,International Journal of Applied Engineering Research,V-9,I-22,P-7398-7401
23) Kerinab Beenu G., Pavithra J.,A study on the prospective consumerâ€ $\mathrm{TM}_{\mathrm{S}}$ perception towards utility cars in Chennai city,2014,International Journal of Applied Engineering Research,V-9,I-22,P-7526-7531

24) Pavithra J., Dilli Babu P., Ambuli T.V.,A study on budgetary control at Maruti Service Masters, Chennai,2014,International Journal of Applied Business and Economic Research,V-12,I-2,P-151-161

25) Pavithra J., Dilli Babu P., Ambuli T.V.,A study on customer satisfaction of retro Garments Pvt Ltd, Chennai,2014,International Journal of Applied Business and Economic Research,V-12,I-2,P-381-391

26) Kerinab Beenu G.H., Pavithra J., Senthilmurugan P.,A study on the influence of promotional activities for TATA ARIA among consumers in Chennai,2014,International Journal of Applied Engineering Research,V-9,I-22,P-7572-7578

27) Vijayaragavan S.P.,An investigative expert that's general FBG sensors,International Journal of Mechanical Engineering and Technology,V-8,I-8,PP-1500-1505,Y-2017

28) Vijayaragavan S.P.,Equalization routing protocol for $\mathrm{Wi}-\mathrm{Fi}$ sensor strategy,International Journal of Mechanical Engineering and Technology,V-8,I-8,PP-1662-1666,Y-2017

29) Karthik B., Kiran Kumar T.V.U., Vijayaragavan P., Bharath Kumaran E.,Design of a digital PLL using 0.35 $\hat{\mathrm{I}}^{1 / 4 \mathrm{~m}}$ CMOS technology,Middle East Journal of Scientific Research,V-18,I-12,PP-1803-1806,Y-2013

30) Kanniga E., Selvaramarathnam K., Sundararajan M.,Kandigital bike operating system,Middle - East Journal of Scientific Research,V

31) Jasmin M., Vigneshwaran T., Beulah Hemalatha S.,Design of power aware on chip embedded memory based FSM encoding in FPGA,International Journal of Applied Engineering Research,V-10,I-2,PP-4487-4496,Y-2015

32) Jasmin M.,Optimization techniques for low power VLSI circuits,Middle East Journal of Scientific Research,V-20,I-9,PP-1082-1087,Y-2014

33) Jasmin M., Vigneswaran T.,Fuzzy controller for error control of on - Chip communication,2017 International Conference on Algorithms, Methodology, Models and Applications in Emerging Technologies, ICAMMAET 2017,V-2017-January,I-,PP-1-5,Y-2017

\section{AUTHORS PROFILE}

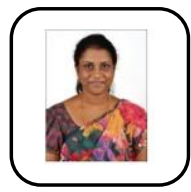

Magdalene Peter Assistant Professor, Department of MBA, Bharath Institute of Higher Education and Research, Chennai, India.

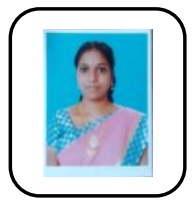

Dr. S. Fabiyola Kavitha Associate Professor, Department of MBA, Bharath Institute of Higher Education and Research, Chennai, India. 